\title{
Removal of Heavy Metal Mercury (Hg) Liquid Waste through Electrolysis Method in Paya Ateuk Village, Pasie Raja District, South Aceh
}

\author{
Darmawan, Susy Sriwahyuni
}

Faculty of Public Health, University of Teuku Umar, Aceh, Indonesia

Corresponding author: Darmawan, e-mail:darmawan@utu.ac.id

Co-author : SS: Susy Sriwahyuni,e-mail: Susisriwahyuni@utu.ac.id

Submitted:30/08/2021 Revised: 27/09/2021 Accepted: 01/10/2021 Published online: 30/10/2021

\begin{abstract}
DOI: https://doi.org/10.35308/j-kesmas.v7i2.4062 How to cite this article: How to cite this article: Darmawan \& Sriwahyuni. S. (2021). Removal of Heavy Metal Mercury (Hg) Liquid Waste through Electrolysis Method in Paya Ateuk Village, Pasie Raja District, South Aceh. J-Kesmas: Jurnal Fakultas Kesehatan Masyarakat (The Indonesian Journal of Public Health). 8(2): 95-98.
\end{abstract}

\begin{abstract}
Electrolysis is one of the methods used to remove heavy metal mercury ( $\mathrm{Hg}$ ). The electrolysis process is carried out on residual liquid waste from gold processing by utilizing chemical reactions through electrodes immersed in an electrolyte solution. This research method is experimental. We conducted laboratory tests to see the electrolysis process on the residual liquid waste from gold processing in a 10-litre container. We took samples from 10 different containers, 1 litre each from each tub. Sampling time was carried out in the morning, afternoon and evening. The results showed a significant decrease in mercury (Hg) levels up to $1.30 \%$ with 12 volts of electricity for 100 minutes. In contrast, the lowest decrease occurred in the electric current of 3.3 volts within 25 minutes. We use the electrolysis method. This heavy metal removal technique can be applied and managed properly by the community and local government to minimize heavy metal pollution such as mercury in the surrounding environment due to waste from the community's traditional gold processing.
\end{abstract}

Keywords: Mercury; Electrolysis; Processing; Gold; Traditional

\section{Introduction}

Mercury metal is a toxic and dangerous chemical element. Mercury comes to the environment through human activities, as found in the gold mining process. The gold mining process is known as amalgamation (extracting gold by mixing gold ore with mercury). The amalgamation process has become a trend due to the simple method and lower cost than other processes. Gold ore processing can increase people's income but cause losses if not done correctly and produce waste (Mirdat, 2013). It is dangerous for humans to consume food and water from contaminated sources of mercury (Irsan et al. 2020). In Indonesia, mercury pollution is found in many places, but there have never been any investigations or reports of people suffering from Minamata disease or mercury poisoning. Traditional gold mining without a permit (PETI) is found in various places, shown in the results of Mirdat's 2013 research conducted in Palu City that there are concentrations of mercury $(\mathrm{Hg})$ in the soil in gold mines ranging from $0.057 \mathrm{ppm}$ to $8.19 \mathrm{ppm}$. (Mirdat, 2013).

The research in Central Lombok and West Lombok in 2014 showed that mercury levels in the soil were detected in $72 \%$ of soil locations around gold mining. The results of the analysis of the mercury content in the soil exceed the allowable threshold
(Astiti\&Sugianti, 2014). The other studies also showed that mercury levels in three sample locations, namely $\mathrm{A}, \mathrm{B}$, and C, respectively: $1.392 \mathrm{ppm}, 1.5912 \mathrm{ppm}$, and $3.1975 \mathrm{ppm}$, have exceeded the standards set by the government through the Decree of the Minister of the Environment of the Republic of Indonesia Number 115 of 2003; the mercury $(\mathrm{Hg})$ threshold in class $\mathrm{C}$ water is 0.002 ppm (Mariwy et al., 2019). Electrolysis is a chemical reaction process in which an electrode is immersed in an electrolyte solution when a voltage is applied to the electrode (Marliana E et al., 2013). This is following (Wiharti et al., 2014), which states that electrolysis is an event when a solution is decomposed into its ions; positive ions (cations) and negative ions (anions) when direct current flows into the electrolyte solution through the electrodes. Oxidation-reduction, or redox reactions, involve changes in the oxidation states of the reactants. There is an actual loss of electrons by one reactant and an equivalent electron by another. When the flow of electrons accompanying a reaction creates a current for electricity, the chemical change is called electrochemistry.

South Aceh has natural resources spread in several locations including Labuhan Haji, Meukek, Sawang, Pasie Raja, and Kluet Tengah. From these subdistricts, 12 villages have traditional gold processing logs. The community used gold ore processing equipment with $\operatorname{logs}$ based on an initial survey 
conducted in PayaAteuk Village, Pasie Raja District, South Aceh Regency. Gold mining waste in PayaAteuk Village, Pasie Raja District, South Aceh comes from local mining carried out by the community. The impact of mercury on the gold mining process $(\mathrm{Hg})$ is very dangerous to the aquatic environment and public health. Therefore, a solution to reduce mercury $(\mathrm{Hg})$ levels from processing the gold ore utilizing electrolysis of liquid waste treatment methods is needed. Research on the removal of mercury $(\mathrm{Hg})$ liquid waste in gold mining in Paya Ateuk Village, Pasi Raja District, South Aceh Regency is conducted to reduce the mercury $(\mathrm{Hg})$ content in the reservoir used to dispose of and accommodate gold mine liquid waste. The purpose of this study was to find out how electrolysis removal techniques in mercury waste can reduce mercury levels in wastewater from traditional gold processing in PayaAteuk Village, Pasi Raja District, South Aceh.

\section{Method}

The research was carried out from August 2020 to January 2021. First, we conducted a site survey; second, we took care of the research permit. After that, we started to test the sample. We also carry out assembly on electrolysis equipment by adjusting variations in power and voltage - contact time. The research sample is the traditional gold processing liquid waste in Paya Ateuk Village, Pasi Raja District, South Aceh Regency. This research method is experimental. The tools we use in this study are an electrolysis bath and an electrode plate. The electrolysis tub is $15 \mathrm{~cm}$ long, $10 \mathrm{~cm}$ wide, and $15 \mathrm{~cm}$ high. The electrode plate consists of 3 cathodes and three anodes made of aluminium. The variables measured or observed in this study were removal through electrolysis with electric currents ranging from $(0.3,3,5$, and 12$)$ at various electrolysis contact times $(0,25,50,75$, and 100) and to remove heavy metal mercury $(\mathrm{Hg})$ in gold processing wastewater.

\section{Results}

Table.1. Results of Mercury (Hg) Decreasing Parameters with Variations of Electric Voltage Volts and Electrolysis Time

\begin{tabular}{|c|c|c|c|c|c|c|c|}
\hline Volt Electrical Voltage & & Elect & sis Min & Time & & Amount & Average \\
\hline 0 & $\mathbf{0}$ & 25 & 50 & 75 & 100 & & \\
\hline 3,3 & 0.0723 & 0.0434 & 0.0162 & 0.0348 & 0.0322 & 0.0745 & 0.0149 \\
\hline 5 & 0.0723 & 0.0342 & 0.033 & 0.0258 & 0.0226 & 0.0721 & 0.01442 \\
\hline 12 & 0.0723 & 0.037 & 0.0258 & 0.0238 & 0.0336 & 0.0704 & 0.01408 \\
\hline 0 & 0.0723 & 0.0142 & 0.0134 & 0.0124 & 0.0115 & 0.0664 & 0.01328 \\
\hline Amount & 0.0723 & 0.0584 & 0.0568 & 0.0552 & 0.0534 & & \\
\hline Average & 0.0723 & 0.0146 & 0.0142 & 0.0138 & 0.01335 & & \\
\hline
\end{tabular}

(Source. Primary Data 2021)

Table 2. Calculation Results for Mercury Hg. Parameter Decrease

\begin{tabular}{ccccc}
$\begin{array}{c}\text { Volt Electrical } \\
\text { Voltage }\end{array}$ & $\begin{array}{c}\text { Electrolysis Minute } \\
\text { Time }\end{array}$ & $\begin{array}{c}\text { Mercury Levels Before } \\
\text { Electrolysis Treatment }\end{array}$ & $\begin{array}{c}\text { Mercury Level After } \\
\text { Electrolysis }\end{array}$ & $\begin{array}{c}\text { Percentage Decrease } \\
\text { in Mercury Levels }\end{array}$ \\
\hline 3,3 & 25 & 0.0723 & 0.0147 & 1.01 \\
& 50 & 0.0723 & 0.0144 & 1.03 \\
& 75 & 0.0723 & 0.0142 & 1.05 \\
5 & 100 & 0.0723 & 0.0139 & 1.07 \\
& 25 & 0.0723 & 0.0146 & 1.02 \\
& 50 & 0.0723 & 0.0141 & 1.06 \\
12 & 75 & 0.0723 & 0.0137 & 1.09 \\
& 100 & 0.0723 & 0.0131 & 1.14 \\
& 25 & 0.0723 & 0.0142 & 1.05 \\
& 50 & 0.0723 & 0.0134 & 1.11 \\
& 75 & 0.0723 & 0.0124 & 1.20 \\
& 100 & 0.0723 & 0.0115 & 1.30 \\
\hline
\end{tabular}

(Source. Primary Data 2021) 


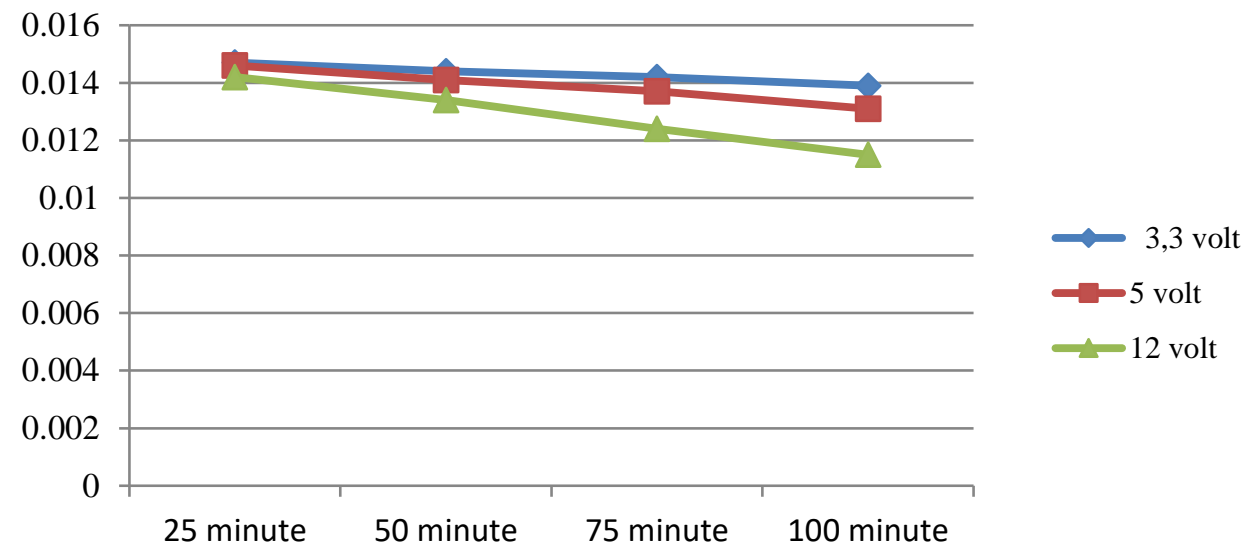

Figure 1 . Decrease in Mercury $(\mathrm{Hg})$ Parameters

Based on the results of testing in the laboratory, as shown in table 1 , there were a decrease in mercury $(\mathrm{Hg})$ parameters in gold mining liquid waste by testing parameters through electric current voltages of $0.3,3.5$, and 12 with electrolysis time of $0,25,50,75$ and 100 minutes. The most significant decrease in mercury $(\mathrm{Hg})$ parameter of 0.0534 occurred at 12 volts for 100 minutes. The lowest decrease was at 3.3 volts at a voltage of 25 volts. Based on Figure 1, there were a significant decrease in mercury $(\mathrm{Hg})$ levels from $1.30 \%$ with the provision of 12 Volt electricity for 100 minutes. The lowest decrease was at 3.3 volts at a voltage of 25 volts in 100 minutes.

\section{Discussion}

\section{Mercury (Hg) Parameters Decrease}

This study's decrease in mercury $(\mathrm{Hg})$ parameters varied greatly in traditional gold mining liquid waste. The sample was taken in UteunAteuk Village after testing through the electrolysis method. The mercury $(\mathrm{Hg})$ parameter decreased by $1.30 \%$, which occurred at 12 volts with 100 minutes. In contrast, the lowest decrease was at 3.3 volts at a voltage of 25 volts. Furthermore, it can be seen in the concentration of mercury $\mathrm{Hg}$ at the cathode, where there is a reduction in positive ions in the direction of the cathode and receiving current signals from electrons. Negative ions also move towards the anode and release electrons. The released electrons will be attracted by mercury ions $(\mathrm{Hg})$ and form mercury metal $\mathrm{Hg}$. The reaction that occurs through the electrolysis method at the cathode is a reaction from reduction. The reaction of the mercury metal ion $(\mathrm{Hg})$ has precipitated on the cathode plate. The water solvent will turn into hydrogen gas $(\mathrm{H} 2)$.

Friday's First Law describes how electrolysis works, the number of electric volts, and electrolysis time. Based on the research results in Tables 1 and 2, the highest decrease in mercury $(\mathrm{Hg})$ parameters did not occur at small currents because of the expected side reactions. However, it is tough to predict what reactions occur at the electrodes during the electrolysis process. The actual reaction in the electrolysis process will follow the relative potential value, namely the standard of the substances involved in the reaction. Wastewater treatment using an electrolysis process requires a device to regulate the voltage called a voltage regulator. A voltage regulator is a device mounted on a generator to regulate the voltage or wave amplitude so the generator remains stable (Gunadin, 2008).

The concentration that is owned varies greatly and the time specified at the time of testing. In addition, other factors that affect the mercury parameter are that the concentration increases at each variation of the test time as the process of examining waste through a pump to an electrolysis reservoir and perfect mixing do not occur in a non-homogeneous reservoir. In this study, the volts used were $25,50.75$, and 100 , while the volume treated was 3 litres at the stage. Because the waste treated in the range has not exceeded the quality standard threshold, the electrolysis process runs smoothly and uses a small voltage volt. The process runs well, a decrease in mercury parameters in wastewater is seen.

The study results analyzed the mercury content of $\mathrm{Hg}$ in sediments in the waters of Kao Bay, North Halmahera, which did not meet the Quality Standards for Quality Raw Materials following Government Regulation No. 82 of 2001 class I. $0.001 \mathrm{mg} / \mathrm{L}$ class II. $0.002 \mathrm{mg} / \mathrm{L}$ class III. $0.002 \mathrm{mg} / \mathrm{L}$ and class IV 0.005 $\mathrm{mg} / \mathrm{L}$ (Kahirunnisa, 2017). Gold processing activities also require large amounts of water. Therefore, gold processing sites are often found along rivers. This condition resulted in waste containing mercury being distributed into the Wamsai River and Kayeli Bay. As 
a result of the use of mercury, in a study conducted by Male et al. (2013), it was found that the mercury concentration in the waste pond was $680 \mathrm{ppm}(\mathrm{mg} / \mathrm{Kg})$ and in the sediments of the Wamsait River and Kayeli Bay of 0.35-7.66 ppm or had exceeded the threshold (Male et al., 2013). This is due to gold mining activities around which pollution will increase the risk of the community being exposed to mercury in the long term. It will be harmful to health if there are no excellent management efforts from various parties, both gold mining managers and the local government, to reduce the amount of mercury concentration in the surrounding environment.

\section{Conclusion}

Based on the results of this study, it can be concluded that mercury levels in the waste from gold mines processing can be reduced by the electrolysis method with a time of 100 minutes and with a voltage of 12 volts decreased significantly by $1.30 \%$. The researcher suggests reducing mercury levels more in 100 minutes by adding a more significant electrical voltage. Under these circumstances, the mercury contained in the waste processing at the gold mine does not pollute the environment around the gold mine PayaTeuk Village, PasiRaja District, South Aceh. The results of the mercury waste analysis will be used as a reference for further processing using the electrolysis method. In addition, the results from this research will also be disseminated in the future to the Bappeda Aceh Selatan as a policyholder.

\section{Acknowledgement}

Thank you to the University of Teuku Umar and the Faculty of Health, who have supported research funds. Also, to the entire research team, lecturers, and students who helped this research, both in the preparation of proposals, data collection, data processing, and in the process of scientific publications.

\section{Author Contribution}

The principal researcher is the first researcher whose role is to prepare ideas, arrange research proposals, determine research locations, determine research budgets as needed, process data, and make journals. Besides, the second researcher is a member of researchers who assists all processes, preparing the necessary equipment needed and assisting the research process in the field.

\section{References}

Astiti \& Sugianti. (2014). Impact of Traditional Gold Mining on the Environment and Animal Feed on Lombok Island. Animal Science Vol. 12(2):101106.

Irsan, et al., (2020). Analysis of Mercury (Hg) Content in the Ecosystem of the Waelata River and Anahoni River Affected by Gold Mining Activities on Buru Island, Maluku.Chem. Prog. 13(1).

Khairunnisa. (2017). Mercury $(\mathrm{Hg})$ in Blood in Traditional Gold Miners in Pumpung Village, Cempaka District, Banjar Baru City. Scientific papers. Borneo Lestari Health Analyst Academy Diploma III Health Analyst Study Program.

Mariwy, et al. (2019). Analysis of Mercury (Hg) Levels in Water Bodies at Several Points of the Waiapu River, Buru Regency. 9(2): 116-122.

Mirdat. 2013. Heavy Metal Mercury (Hg) in Soil in the Gold Mine Processing Area in Poboya Village. Palu City. Journal of Agrotekbisnis.1(2):127-134.

Male, Y.T., Brushett, A.J.R., Pocock, M. \& Nanlohy, A. (2013). Recent Mercury Contamination from Artisanal Gold Mining on Buru Island, IndonesiaPotential Future Risks to Environmental Health and Food Safety. Marine Pollution Bulletin. 77 (1-2): 428-433.

Marlina E, Wahyudi S, Yuliati L. (2013). Production of Brown's gas from the electrolysis of $\mathrm{H} 2 \mathrm{O}$ with a NaHCO3 catalyst. Journal of Mechanical Engineering. 4(1): 53-58

Purnawan, P.S. (2013). Distribution of Mercury in Marine Sediments Around the Puboya River Estuary. Tadulako University Journal. Tadulako.

WHO. (2008). Hazards of Chemicals on Health and Environment. EGC Medicine Book. Jakarta.

Wahyono Y, Sutanto H. Hidayanto E. (2017). Production of Hydrogen Gas Using the Electrolysis Method of Water and Seawater Electrolytes with $\mathrm{NaOH}$ Catalyst. Youngster Physics Journal. 6(4): 353-359.

Wiharti, Riyanto, Fitri N. (2014). Application of Electrolysis Method Using Platinum (Pt) Copper $\mathrm{Cu}$ Electrodes in Liquid Waste of Leather Tanning Industry at Stimulyo Market, Payungan Bantul Yogyakarta. Indonesian Journal of Chemical Research. 